\title{
BIJAK MENGGUNAKAN MEDIA SOSIAL DI KALANGAN PELAJAR MENURUT UNDANG-UNDANG NOMOR 19 TAHUN 2016 TENTANG INFORMASI DAN TRANSAKSI ELEKTRONIK
}

\author{
Ivan Fauzani Raharja \\ Program Khusus Hukum Administrasi Negara Fakultas Hukum Universitas Jambi \\ JI.Raya Jambi - Ma.Bulian KM. 15 \\ ivanfauzani_fh@unja.ac.id
}

\begin{abstract}
This article will discuss the dangers of hoax news and the legal impact of not being able to use social media wisely. The object of research in this study were students of junior high school and senior high school, based on the results of this study it was found that the students in the two schools were aware that the legal impact in terms of social media abuse, the impact of ITE and also the sanctions obtained if there is abuse of social media and hoax news that is not necessarily true. The basis of this research to take samples in the two schools is because, young people in a condition of thinking that is still very innocent, they would certainly be very easy to be told to spread the chain to other friends or others. We also have to realize that the ability of teenagers in studying and studying is still very minimal, especially if the hoax is boarded with certain interests that are packed with funny videos. At their young age, those who used to look for sensations. There are even some of our children who actually feel proud that their wrongdoing is the center of attention. Some even deliberately become perpetrators or perpetrators' profiles, because they want to be famous and feel great because they dare to make mistakes. The research method used is to use empirical research methods in which the data in this study are directly sought and examined in the field, empirical data analysis techniques, namely data obtained and arranged systematically and analyzed diagnostically and prescriptive in describing data in writing.
\end{abstract}

Keywords: Legal Awareness, Information and Electronic Transactions, Legal.

\begin{abstract}
Abstrak
Artikel ini membahas mengenal bahaya berita hoax dan juga dampak hukum akibat tidak dapat menggunakan media sosial dengan bijak. Objek penelitian pada penelitian ini adalah siswa/siswi Sekolah Menengah Pertama dan Sekolah Menengah Atas, berdasarkan hasil penelitian ini didapati bahwa siswa/siswi di dua sekolah tersebut menyadari bahwa dampak hukum dalam hal penyalahgunaan media sosial, dampak ITE dan juga sanksi yang didapat apabila terjadi penyalahgunaan terhadap media sosial dan berita hoax yang belum tentu kebenarannya. Dasar penelitian ini mengambil sampel di dua sekoah tersebut adalah dikarenakan, anak muda dalam kondisi pemikiran yang masih sangat polos, mereka tentu akan sangat mudah untuk disuruh menyebar luaskan secara berantai ke teman yang lain atau orang lain. Kita pun harus menyadari bahwa kemampuan anak remaja dalam menelaah dan mengkaji masih sangatlah minim, apalagi jika hoax teesebut ditumpangi dengan kepentingan tertentu yang dikemas dengan video lucu. Pada usia muda mereka, yang biasa suka cari sensasi. Bahkan ada sebagian dari anak-anak kita yang justru merasa bangga kalau perbuatan salah mereka menjadi pusat perhatian orang banyak. Bahkan ada yang dengan sengaja malah menjadi pelaku atau profil pelaku, karna ingin terkenal dan merasa hebat karena berani berbuat salah. Metode penelitian yang digunakan adalah dengan menggunakan metode penelitian empiris yang mana data dalam penelitian ini langsug dicari dan diteliti dilapangan, teknik analisis data empiris, yaitu data yang diperoleh dan disusun secara sistematis dan dianalisis secara diagnostic dan preskriptif dalam menguraikan data dalam bentuk penulisan.
\end{abstract}

Kata Kunci : Kesadaran Hukum, Informasi dan Transaksi Elektronik, Hukum. 


\section{Pendahuluan}

Pemanfaatan Teknologi Informasi, media dan komunikasi dalam masyarakat khususnya remaja siswa telah mengubah baik perilaku masyarakat maupun peradaban manusia secara global. Perkembangan teknologi informasi dan komunikasi telah pula menyebabkan hubungan dunia menjadi tanpa batas (borderless) dan menyebabkan perubahan sosial, ekonomi dan budaya secara signifikan berlangsung demikian cepat. Teknologi Informasi saat ini menjadi pedang bermata dua karena selain memberikan kontribusi bagi peningkatan kesejahteraan, kemajuan dan peradaban manusia, sekaligus menjadi sarana efektif perbuatan melawan hukum.

Perkembangan teknologi komunikasi saat ini sangatlah pesat, teknologi komunikasi yang diiringi dengan kehadiran media massa dan media sosial juga telah memberi banyak perubahan dalam kehidupan bermasyarakat. Literasi informasi diterima oleh masyarakat sebagai keterampilan yang penting untuk dikuasai selain kemampuan teknologi informasi. Di era di mana informasi serba mudah didapat dan serba melimpah, maka keterampilan tersebut menjadi kemampuan mendasar yang diperlukan untuk membantu dalam menyelesaikan permasalahannya atau menyelesaikan tugastugasnya dengan memanfaatkan informasi secara etis dan efisien. Kemampuan mendasar ini idealnya menjadi modal yang dimiliki oleh masing-masing individu untuk melaksanakan pada tahap perencanaan, pelaksanaan, pengambilan manfaat, dan evaluasi pada berbagai program. ${ }^{1}$

Perkembangan yang sangat pesat terhadap media sosial akhir-akhir ini dapat menjadi topik hangat untuk dibahas karena banyak orang yang memakai media sosial namun mereka kurang memahami media sosial itu sendiri. Media sosial teknologi mengambil berbagai bentuk termasuk majalah, forum internet, weblog, blog sosial, microblogging, wiki, podcast, foto atau gambar, video, peringkat dan bookmark sosial. Adapun ciri dari media sosial adalah sebagai berikut:

1. Pesan yang disampaikan tidak hanya untuk satu orang saja namun bisa ke berbagai banyak orang contohnya pesan melalui SMS ataupun internet;

2. Pesan yang disampaikan bebas, tanpa harus melalui suatu gatekeeper,

3. Pesan yang disampaikan cenderung lebih cepat di banding media lainnya; dan

4. Penerimaan pesan yang menentukan waktu interaksi.

Saat ini telah lahir suatu rezim hukum baru yang dikenal dengan hukum siber atau hukum telematika. Hukum siber atau cyber law, secara internasional digunakan untuk istilah hukum yang terkait dengan pemanfaatan teknologi informasi dan komunikasi. Demikian pula, hukum telematika yang merupakanperwujudan dari konvergensi hukum telekomunikasi, hukum media dan hukum informatika. Istilah lain yang juga digunakan adalah hukum teknologi informasi (law of information technology), hukum dunia maya (virtual world law) dan hukum mayantara. Istilah-istilah tersebut lahir mengingat kegiatan yang dilakukan melalui jaringan sistem komputer dan sistem komunikasi baik dalam lingkup lokal maupun global (internet) dengan memanfaatkan teknologi informasi berbasis sistem komputer yang merupakan sistem elektronik yang

1 Mochammad Ali Maulidin, Syahirul Alim dan Viani Puspita Sari. "Cerdas dan Bijak Dalam Memanfaatkan Media Sosial Di Tengah Era Literasi dan Informasi." Jurnal Aplikasi Ipteks Untuk Masyarakat, Maret 2017: Vol 6, No 1, hlm. 1. 
yang dapat dilihat secara virtual.

Media sosial saat ini bekerja dengan sistem internet, internet yang merupakan kepanjangan dari interconnection networking adalah hubungan jaringan besar dari jaringan-jaringan komputer yang menghubungkan orang-orang dan komputerkomputer di seluruh dunia, baik melalui telepon, satelit, dan sistem-sistem komunikasi lainnya. ${ }^{2}$ Berdasarkan hal tersebut muncullah permasalahan hukum yang seringkali dihadapi ketika terkait dengan penyampaian informasi, komunikasi dan/atau transaksi secara elektronik, khususnya dalam hal pembuktian dan hal yang terkait dengan perbuatan hukum yang dilaksanakan melalui sistem elektronik. Yang dimaksud dengan sistem elektronik adalah sistem komputer dalam anti luas, yang tidak hanya mencakup perangkat keras dan perangkat lunak komputer, tetapi juga mencakup jaringan telekomunikasi dan/atau sistem komunikasi elektronik.

Pesatnya perkembangan media sosial, kini dikarenakan semua orang seperti bisa memiliki media sendiri. Jika untuk memiliki media tradisional seperti televisi, radio atau koran dibutuhkan modal yang besar dan tenaga kerja yang banyak, maka lain halnya dengan media. Seorang pengguna media sosial bisa mengakses menggunakan media sosial dengan jaringan internet bahkan yang aksesnya lambat sekalipun, tanpa biaya besar, tanpa alat mahal dan dilakukan sendiri. Pengguna media sosial dengan bebas bisa mengedit, menambahkan, memodifikasi baik tulisan, gambar, video, grafis dan berbagai model content lainnya.

Berdasarkan perkembangan tersebut maka semua hal ini berkumpungan dengan perangkat keras dan perangkat lunak yang terdapat pada suatu alat teknologi yang ada, dalam hal ini perangkat lunak mempunyai andil yang sangat dominan dalam peran menggunakan media sosial. Perangkat lunak atau program komputer adalah sekumpulan instruksi yang diwujudkan dalam bentuk bahasa, kode, skema, ataupun bentuk lain, yang apabila digabungkan dengan media yang dapat dibaca dengan komputer akan mampu membuat komputer bekerja untuk melakukan fungsi khusus atau untuk mencapai hasil yang khusus, termasuk persiapan dalam merancang instruksi tersebut. Sistem elektronik juga digunakan untuk menjelaskan keberadaan sistem informasi yang merupakan penerapan teknologi informasi yang berbasis jaringan telekomunikasi dan media elektronik, yang berfungsi merancang, memproses, menganalisis, menampilkan dan mengirimkan atau menyebarkan.

Media sosial sesungguhnya memiliki sebuah konsep yang sangat sederhana, yaitu adalah mengenai menjadi manusia biasa. Manusia biasa yang saling membagi ide, bekerjasama dan berkolaborasi untuk menciptakan kreasi, berfikir, berdebat, menemukan orang yang bisa menjadi teman baik, menemukan pasangan dan membangun sebuah komunitas. Intinya, menggunakan media sosial menjadikan kita sebagai diri sendiri. Selain kecepatan informasi yang bisa diakses dalam hitungan detik, menjadi diri sendiri dalam media sosial adalah alasan mengapa media sosial berkembang pesat. Tak terkecuali, keinginan untuk aktualisasi diri dan kebutuhan menciptakan personal branding.

Indonesia merupakan salah satu negara dengan pengguna media sosial paling atraktif di

2 Pamela Felita, dkk. "Pemakaian Media Sosial dan Self Concept Pada Remaja." Jurnal IImiah Psikologi MANASA, Maret 2016: Vol 5, No 1, hlm. 31. 
dunia. Seringkali berbagai isu di dalam negeri menjadi trending topic di media sosial atau viral (cepat menyebar dan populer) di situs jejaring sosial lainnya. Menurut data We Are Social tentang statistik digital dunia yang dirilis Januari 2016, Indonesia memiliki 88,1 juta pengguna internet aktif, meningkat $15 \%$ dalam dua belas bulan terakhir. Survei Litbang Kompas pada Juni 2015 di lima belas kota (di luar Jakarta) dengan 6.000 responden menunjukkan empat dari sepuluh responden mengaku memiliki perangkat ponsel pintar. Sekitar $85 \%$ diantaranya aktif mengakses internet via ponsel. Tak kurang dari $61 \%$ responden juga mengaku lebih banyak mengakses media sosial. Fakta ini menunjukkan bahwa media sosial telah menjadi ruang publik baru perbincangan sosial politik. Sejak munculnya jejaring sosial di Indonesia menimbulkan dampak yang cukup signifikan dalam kehidupan sosial masyarakat. Istilah jejaring sosial ini diperkenalkan pertama kalinya oleh Prof. J.A. Barnes pada tahun 1954. Jejaring sosial adalah suatu struktur sosial yang dibentuk dari simpul-simpul (yang umumnya adalah individu atau organisasi) yang diikat dengan satu atau lebih tipe relasi spesifik seperti nilai, visi, ide, teman, keturunan dan lain-lain. Jejaring ini menunjukkan jalan di mana mereka berhubungan karena kesamaan sosialitas, mulai dari mereka yang dikenal sehari-hari sampai dengan keluarga. Perkembangan teknologi membentuk pemanfaatan jejaring sosial yang saat ini digunakan dengan istilah "media sosial" dan dikuti dengan berbagai situs bermunculan, situs komunitas/jaringan sosial sebuah fenomena internet yang mewakili generasi muda. Seperti yang populer pertama kalinya di Indonesia adalah Friendster dan Myspace serta
Facebook lalu diikuti pula dengan Youtube dan Twitter dan lainnya.

Munculnya jejaring sosial versi maya ini, mempengaruhi relasi antar manusia umumnya remaja. Situs komunitas di atas dibuat untuk memenuhi keinginan individu untuk berkomunikasi tanpa ada batasan ruang dan waktu. Tak jarang jejaring sosial kerap berpotensi mempengaruhi pola berpikir seseorang dan membentuk kepribadian individu. Besarnya pengguna media sosial di kalangan pelajar Sekolah Menengah Pertama dan Sekolah Menengah Atas saat ini tidak luput pula penyebarannya sampai ke pelosok negeri. Namun para pengguna media sosial tersebut sangat minim mendapat informasi mengenai keberadaan UndangUndang Nomor 19 Tahun 2016 tentang Informasi dan Transaksi Elektronik, yang merupakan salah satu produk hukum yang membatasi kebebasan dari para pengguna media sosial agar lebih bijak dalam penggunaannya khususnya pada kalangan remaja.

Sebagaimana yang kita ketahui bahwa remaja merupakan komunitas terbesar dalam masyarakat Indonesia yang menggunakan media sosial secara regular. Alasan awal mereka sangat aktif menggunakan media sosial adalah untuk mencari perhatian, meminta pendapat dan menumbuhkan citra, namun lama kelamaan akhirnya menjadi ketergantungan. Walaupun media sosial memberikan dampak positif pada remaja, namun pada saat mereka sulit melepaskan diri dari kegiatan yang berkaitan dengan media sosial maka akan memberikan dampak yang kurang positif. Sejumlah studi menunjukkan bahwa akibat penggunaan media sosial yang berlebihan, remaja ditemukan mengalami ingkongruensi pada konsep 
dirinya. ${ }^{3}$

Bagi masyarakat modern yang kini sudah sangat akrab dengan internet, jejaring sosial, tentu bukan hal yang asing lagi. Ada banyak jenis jejaring sosial yang digunakan masyarakat, terutama anak muda untuk menjalin pertemanan atau fungsi lainnya. Meskipun awalnya jejaring sosial tidak dimaksudkan untuk digunakan sangat sering, namun faktanya saat ini jejaring sosial hampir menguasai hidup penggunanya, terutama anak muda.

Saat ini media sosial sudah banyak sekali jenisnya, bahkan sangking banyaknya akan membuat para penggunanya bingung dalam memilih media sosial apa yang cocok untuknya. Tapi pada intinya sosial media hanya memiliki satu fungsi yaitu untuk menjalin komunikasi secara online. Selanjutnya, teknologi internet dan mobile phone makin maju maka media sosial pun ikut tumbuh dengan pesat. Kini untuk mengakses Facebook atau Twitter misalnya, bisa dilakukan dimana saja dan kapan saja hanya dengan menggunakan sebuah mobile phone. Demikian cepatnya orang bisa mengakses media sosial mengakibatkan terjadinya fenomena besar terhadap arus informasi tidak hanya di negara-negara maju, tetapi juga di Indonesia. Karena kecepatannya media sosial juga mulai tampak menggantikan peranan media massa konvensional dalam menyebarkan berita-berita. Sehingga, sebagai pengguna media sosial dengan bebas bisa mengedit, menambahkan, memodifikasi baik tulisan, gambar, video, grafis dan berbagai model content lainnya.

Dalam menggunakan jejaring sosial, kita diberi kebebasan berbagi informasi atau berkomunikasi dengan siapa saja. Kebebasan ini bukan berarti tidak ada etika yang membatasi mana yang boleh atau mana yang tidak boleh. Ada baiknya kita mengenal bagaimana etika yang harus diperhatikan dalam menggunakan jejaring sosial. Hal ini dilakukan agar membuat pengguna merasa nyaman dan mengurangi tindak kejahatan. Dalam melakukan komunikasi antar sesama pada situs jejaring sosial, biasanya kita melupakan etika dalam berkomunikasi. Sangat banyak kita temukan katakata kasar yang muncul dalam percakapan antar sesama di jejaring sosial, baik itu secara sengaja ataupun tidak sengaja. Sebaiknya dalam melakukan komunikasi kita menggunakan kata-kata yang layak dan sopan pada akun-akun jejaring sosial yang kita miliki. Pergunakan bahasa yang tepat dengan siapa kita berinteraksi.

Dalam etika berkomunikasi ada baiknya kita tidak menyebarkan informasi yang berhubungan dengan SARA (Suku, Agama, dan Ras) dan pornografi di jejaring sosial. Sebarkanlah hal-hal yang berguna yang tidak menyebabkan konflik antar sesama pada situs jejaring tersebut. Begitu pula dalam menerima berita ada baiknya dilakukan terlebih dahulu ditelusuri terhadap berita yang menjelekkan orang lain sangat sering kita jumpai di jejaring sosial. Hal tersebut kadang bertujuan untuk menjatuhkan nama pesaing dengan berita-berita yang direkayasa. Oleh karena itu pengguna jejaring sosial dituntut untuk cerdas dalam menangkap sebuah informasi, bila ingin ikut menyebarkan informasi tersebut, ada baiknya kita melakukan kroscek akan kebenaran informasi terlebih dahulu.

Saat menyebarkan informasi baik itu berupa tulisan, foto atau video milik orang lain, ada baiknya kita mencantumkan sumber informasi 
sebagai bentuk penghargaan untuk hasil karya seseorang. Tidak serta merta copy paste tanpa memberikan sumber informasi tersebut, serta jangan terlalu mengumbar informasi pribadi anda karena dalam menggunakan jejaring sosial ada baiknya kita sebagai pengguna harus bijak dalam menginformasikan privasi/kehidupan pribadi. Jangan terlalu mengumbar hal-hal pribadi di jejaring sosial, apalagi sesuatu yang sensitif dan sangat pribadi. Semisal mengenai keuangan, hubungan percintaan, tentang kehidupan keluarga, tentang kejengkelan dengan seseorang, nomor telepon alamat rumah atau keberadaan anda. Hal ini dapat mengganggu kontak lain dalam daftar anda dan bisa menjadi informasi bagi mereka yang ingin berniat jahat kepada kita.

\section{Metode Penelitian}

Suatu penelitian hukum erat kaitanya terhadap konsep hukum yang digunakan bahwa menurut Soetondyo Wigyosoebroto terhadap lima konsep hukum, konsep-konsep hukum tersebut sebagai berikut:

1. Hukum adalah asas kebenaran dan keadilan yang berlaku kodrati dan berlaku universel;

2. Hukum adalah norma-norma positif di dalam sistem perundang-undangan;

3. Hukum adalah apa yang diputuskan oleh hakim (in concreto) dan tersistemasisasi sebagai judge made law;

4. Hukum adalah pola-pola perilaku sosial yang terlembaga eksis sebagai variabel sosial yang empirik; dan
5. Hukum adalah manifestasi makna-makna simbolik para perilaku sosial sebagai tampak dalam interaksi antar mereka. ${ }^{4}$

Pada konsep hukum pertama, kedua dan ketiga sering disebut dengan konsep hukum doktrinal (normatif), konsep hukum ini merupakan suatu norma, baik yang diindentikan dengan keadilan yang harus diterapkan (ius constituedum) atau norma yang dibentuk dalam suatu perintah atau undang-undang (ius constituetum) agar terjamin kepastian hukumnya. Selanjutnya ada pula normanorma yang terdapat dalam putusan-putusan yang merupakan produk hakim (judgements), sehingga penelitian-penelitian yang berdasarkan normanorma hukum tersebut sebagai penelitian doktrinal.

Kemudian pada konsep keempat dan kelima adalah konsep hukum normologi. Menurut Burham Ashofa, hukum dalam konsep ini merupakan bukan sebagai rules akan tetapi sebagai regulaties dalam kehidupan sehari-hari atau pengalaman. ${ }^{5}$ Sehingga hukum di sini sebagai tingkah laku atau aksi-aksi interaksi. Adapun demikian maka penelitian hukum disini disebut sebagai non doktrinal (empiris). Penelitian ini termasuk kedalam penelitian non doctrinal.

\section{Pembahasan}

Perkembangan media sosial secara langsung berdampak terhadap tatanan dan perilaku dari manusia, baik sebagai sarana informasi maupun sebagai sarana sosialisasi dan interaksi antar manusia. Sarana informasi untuk berinteraksi tersebut saat ini cukup banyak diminati dan digunakan oleh masyarakat $d$ unia khususnya di

\footnotetext{
4 Setiono. Pemahaman Terhadap Metodologi Penelitian Hukum. Surakarta: Program Studi llmu Hukum Pasca Sarjana Universitas Sebelas Maret (UNS), 2010, hlm. 20.

5 Burhan Ashofa. Metode Penelitian Hukum. Jakarta: Rineka Cipta, 2007, hlm. 10.
} 
Indonesia. Sarana teknologi informasi ini bisa digunakan dan dapat di akses oleh seluruh masyarakat dengan tidak membeda-bedakan kelas, ras, agama dan antar golongan.

Saat ini penggunaan media sosial telah menjadi bagian dari sebagian besar masyarakat Indonesia. Selain itu media sosial saat ini juga telah di jadikan sebagai tempat untuk saling mendapatkan dan menyebarkan informasi. Namun, sayangnya akibat dari penyalahgunaan sosial media dalam menyebarkan informasi juga berdampak pada banyaknya para pengguna yang masuk ke ranah hukum akibat dari penyebaran informasi pada sosial media yang tidak menggunakan etika. Internet World Stats pada tahun 2012 menyatakan bahwa Indonesia merupakan negara kedelapan yang menggunakan internet terbanyak dari seluruh negara di dunia. ${ }^{6} \mathrm{Hal}$ ini sejalan dengan data dari Statistik Asosisasi Penyelenggara Jasa Internet Indonesia (APJII) yang menyatakan bahwa "jumlah pengguna internet di Indonesia terus mengalami peningkatan yang cukup signifikan. Sebagai contoh pada tahun 1998 pengguna internet di Indonesia adalah 512.000 , kemudian naik menjadi 25 juta pada tahun 2007. ${ }^{7}$

Berdasarkan hasil riset yang dikeluarkan Google pada bulan Maret 2015, Indonesia juga mengalami pertumbuhan dua kali lipat dalam mengadopsi smartphone. Dalam hal ini, $62 \%$ pengguna smartphone menggunakan ponsel mereka untuk mengakses internet. Oleh sebab itu, Indonesia mampu menempati posisi pertama di Asia dan posisi ketiga di dunia terkait dengan akses internet melalui smartphone. ${ }^{8}$

Penggunaan media sosial bisa menjadi nilai yang positif jika para penggunanya menggunakan sarana tersebut untuk hal-hal yang bersifat positif misalnya untuk menambah ilmu pengetahuan, untuk sarana komunikasi dan promosi, untuk sarana mengeksploitasi kemampuan diri dan juga sebagai sarana untuk membangun silaturahmi antar sesama pengguna. Tetapi jika penggunaan media sosial ini digunakan untuk hal yang negatif dan tidak produktif akan berdampak kurang baik terhadap tatanan kepribadian pengguna maupun kepada tatanan budaya dasar masyarakat dan lingkungan.

Dalam upaya mengurangi permasalahan tersebut maka diperlukanlah suatu etika dalam menggunakan media sosial agar tidak saling menghina ataupun menuduh orang lain tanpa alasan yang jelas. Karena pada dasarnya hal seperti itulah yang nantinya akan terjerat hukum karena kurang hati-hati dalam menyebarkan informasi pada internet Dalam mengunakan media sosial dampak negatif harus dapat kita hindari dan dampak positif yang harus diberdayakan, mau tidak mau atau suka tidak suka, teknologi informasi media sosial ini sudah hadir dan ada di tengah-tengah masyarakat pengguna, hanya saja bagaimana kita bisa menyiasati dan memanfaatkan untuk kebaikan pengguna dalam memaanfaatkan teknologi informasi dalam bermedia sosial.

Dengan demikian keberadaan teknologi informasi media sosial secara langsung maupun

6 Hendra. Fenomena Internet Pada Anak-Anak dan Remaja" <http://hendra.room318online.com/FenomenalnternetPadaAnakAnakdanRemaja> diakses pada tanggal 23 Agustus 2018.

7 Qomariah, A.N. "Perilaku Penggunaan Internet Pada Kalangan Remaja di Perkotaan" $<$ http://palimpsest.fisip.unair.ac.id/PerilakuPenggunaanInternetPadaKalanganRemajadiPerkotaan > diakses pada tanggal 23 Mei 2018.

8 Erwin, Z. "Indonesia Juara Akses Internet Melalui Smartphone" <http://tekno.tempo.co/IndonesiaJuaraAksesInternetMelaluiSmartphone> diakses pada tanggal 25 Mei 2018 
tidak langsung sudah bisa merubah tatanan perilaku budaya, baik perilaku budaya pribadi maupun perilaku budaya masyarakat sekitar. Tetapi yang kita harapkan jangan sampai pengaruh teknologi informasi media sosial ini berpengaruh secara fundamental terhadap perilaku budaya masyarakat yang mana Indonesia dikenal dengan budaya adat ketimuran yang menjunjung nilai-nilai sopan santun dan saling menghormati serta perpedoman pada kaidah-kaidah keagamaan.

Pada kalangan remaja menjalin hubungan erat dan harmonis dengan teman sebaya sangatlah penting pada masa remaja. Pengaruh teman sebaya pada sikap, pembicaraan, minat, penampilan dan perilaku lebih besar daripada pengaruh keluarga. Demikian halnya dengan media sosial, salah satu contohnya didapat dari jejaring sosial yang diperoleh remaja melalui teman sebaya dapat mempengaruhi pola penggunaan jejaring sosial oleh remaja. Banyaknya fitur-fitur menarik dalam jejaring sosial/media sosial membuat mereka cenderung malas dan kecanduan.

Keadaan tersebut membuat mereka banyak waktu yang terbuang dan aktivitas yang terganggu, seperti sekolah, belajar, makan, tidur, bersosialisasi dengan lingkungan sekitar dan membantu orang tua. Karena anak tersebut terlalu lelah dengan kesenangan dalam jejaring/media sosial tersebut. Selain dampak negatif, media/jejaring sosial juga memiliki manfaat yang dapat dirasakan oleh penggunanya.

Perkembangan media sosial yang cukup pesat untuk saat ini terbukti dengan banyaknya ragam dan jenis media sosial di kalangan pengguna dan penggunaannya pun bisa dengan menggunakan jasa komputer, Phonsel dan leptop. Alat-alat komunikasi tersebut bisa digunakan oleh pengguna di mana saja dan kapan saja tidak dibatasi oleh ruang dan waktu, sehingga memudahkan pengguna berinteraksi di media sosial. Terlepas dari itu semua yang harus diingat adalah dampak positif dan negatifnya dalam penggunaan media sosial tersebut terutama dampaknya terhadap perilaku masyarakat. Berikut analisa dampak positif dan negatif dari penggunaan sarana media sosial.

Dalam menggunakan media sosial, tentu kita diberikan kebebasan agar bisa berkomunikasi dengan siapa saja. Namun yang sering di salah artikan di sini adalah, bebas bukan berarti tanpa etika. Alangkah baiknya apabila kita mengetahui etika apa saja yang harus diperhatikan pada saat menggunakan jejaring sosial. Tidak sedikit permasalahan sosial yang terjadi akibat kurangnya kesadaran masyarakat dalam beretika dalam sosial media. Justru para pengguna terkadang dibutakan oleh berita yang tidak benar akibat dari hasutan yang beredar pada media sosial.

Saat teknologi internet dan mobile phone makin maju maka media sosial pun ikut tumbuh dengan pesat. Kini untuk mengakses Facebook atau Twitter misalnya, bisa dilakukan dimana saja dan kapan saja hanya dengan menggunakan sebuah mobile phone. Demikian cepatnya orang bisa mengakses media sosial mengakibatkan terjadinya fenomena besar terhadap arus informasi tidak hanya di negaranegara maju, tetapi juga di Indonesia. Karena kecepatannya media sosial juga mulai tampak menggantikan peranan media massa konvensional dalam menyebarkan berita-berita. 
Penggunaan media sosial dilihat oleh remaja sebagai salah satu wadah yang dapat membantu penemuan identitas dirinya. Melalui media sosial, remaja memiliki komunitas online yang memberikan kesempatan bagi remaja untuk berinteraksi secara sosial dengan orang lain dan mendapatkan umpan balik tentang dirinya dari komunitas tersebut. Umpan balik dan evaluasi diri dari komunitas dunia maya ini dianggap penting bagi individu untuk dijadikan pedoman membentuk konsep dirinya. Selain itu, komunikasi melalui dunia maya tidak terlalu membebani dan menakutkan bagi remaja karena remaja dapat mengganti karakternya secara mudah pada media sosial. Dengan kata lain, bagi para remaja komunikasi dunia maya melalui media sosial dianggap sebagai tempat ideal untuk bereksperimen dan melakukan eksplorasi pencarian identitas. Dikarenakan kemudahan dalam menjelajahi dunia media sosial, remaja mengakses media sosial secara terus menerus dan seringkali menimbulkan fenomena penggunaan berlebihan atau ketagihan (addiction) yang mana ini akan menjadi umpan balik dalam hal pemanfaatan dan tindakan melanggar hukum.

$$
\text { Umpan balik dari dunia sosial sangat }
$$
berpengaruh dalam pembentukan dan perkembangan identitas remaja. Elkind mengatakan bahwa identitas remaja dipengaruhi oleh imaginary audience dan personal fable dari remaja tersebut. Imaginary audience adalah kelompok teman-teman (peers) dan orang lain yang dipercaya memperhatikan remaja secara konstan. Personal fable adalah kepercayaan remaja bahwa mereka spesial, unik, dan terhindari dari bahaya. ${ }^{9}$
Berdasarkan hal mengenai umpan balik tersebutkah media sosial dapat menjadi sebuah akibat dan akibat dari penggunaan media sosia yang tidak sesuai dengan aturan yang berlaku. Berdasarkan hal tersebut maka kita harus bijak dalam menggunakan media sosial. Pengaturan mengenai media sosial telah diatur dalam UndangUndang Republik Indonesia Nomor 19 Tahun 2016 Tentang Perubahan Atas Undang-Undang Nomor 11 Tahun 2008 Tentang Informasi dan Transaksi Elektronik.

Undang-Undang Republik Indonesia Nomor 11 Tahun 2008 Tentang Informasi dan Transaksi Elektronik terdapat 13 Bab dan terdapat 54 Pasal yang mana terdiri dari:

1. Bab I Ketentuan Umum;

2. Bab II Asas dan Tujuan;

3. Bab III Informasi, Dokumen, dan Tanda Tangan Elektronik;

4. Bab IV Penyelenggaraan Sertifikat Elektronik dan Sistem Elektronik;

5. Bab V Transaksi Elektronik;

6. Bab VI Nama Domain, Hak Kekayaan Intelektual, dan Perlindungan Hak Pribadi;

7. Bab VII Perbuatan Yang Dilarang;

8. Bab VIII Penyelesaian Sengketa;

9. Bab IX Peran Pemerintah dan Peran Masyarakat;

10. Bab X Penyidikan;

11. BAB XI Ketentuan Pidana;

12. Bab XII Ketentuan Peralihan; dan

13. Bab XIII Ketentuan Penutup.

9 Elkind, D, Egocentrism In Adolescence. Child Development, 1967, hlm. 1025. 
Selanjutnya pada tahun 2016 dilakukanlah perubahan terhadap undang-undang tersebut, yaitu Undang-Undang Republik Indoensia Nomor 11 Tahun 2008, yang mana undang-undang ini menambah bebera ketentuan yang berlaku, yaitu adanya penambahan pada beberapa pasal, yaitu sebagai berikut:

1. Angka 6 dan angka 7 Pasal 1 disisipkan satu (satu) angka, yakni angka 6a;

2. Ketentuan Pasal 5 tetap dengan perubahan penjelasan ayat (1) dan ayat (2);

3. Ketentuan Pasal 26 ditambah 3 (tiga) ayat, yakni ayat (3), ayat (4), dan ayat (5);

4. Ketentuan Pasal 27 tetap dengan perubahan penjelasan ayat (1), ayat (3), dan ayat (4);

5. Ketentuan ayat (3) dan ayat (4) Pasal 31;

6. Ayat (2) dan ayat (3) Pasal 40 disisipkan 2 (dua) ayat, yakni ayat (2a) dan ayat (2b); ketentuan ayat (6) Pasal 40 diubah; serta penjelasan ayat (1) Pasal 40 diubah;

7. Ketentuan ayat (2), ayat (3), ayat (5), ayat (6), ayat (7), dan ayat (8) Pasal 43 diubah; di antara ayat (7) dan ayat (8) Pasal 43 disisipkan 1 (satu) ayat, yakni ayat (7a); serta penjelasan ayat (1) Pasal 43 diubah; dan

8. Ketentuan Pasal 45 diubah serta di antara Pasal 45 dan Pasal 46 disisipkan 2 (dua) pasal, yakni Pasal 45A dan Pasal 45B.

Terjadinya perubahan terhadap undangundang tersebut menunjukkan bahwa pemberlakuan undang-undang sebelumnya masih terdapat kekurangan dan terdapat ketidak sesuaian setekah
8 (delapan) tahun pemberlakuan undang-undang sebelumnya. Pemberlakuan tentang kejahatan pada dunia maya yang mana memiliki payung hukum yang kuat dan memiliki akibat pidana dan/atau memperoleh denda dari kegiatan yang dapat menimbulkan kegaduhan dalam informasi dan pemalsuan dari transaksi elektonik.

Mengenai perbuatan yang dilarang diatur dalam Pasal 27 sampai dengan Pasal 37 UndangUndang Nomor 11 Tahun 2008 dan terdapat beberapa penambahan sesuai dengan perubahan yang telah diterbitkan melalui Undang-Undang Nomor 19 Tahun 2016 Tentang Informasi dan Transaksi Elektonik. Hendaknya setiap lapisan masyarakat menaati peraturan yang berlaku yang telag diundangkan dalam lembaran negara dikarenakan hanya akan menimbulkan kerugian baik secara materil maupu formil.

Dampak positif dalam menggunakan media sosial, yaitu sebagai berikut:

1. Memperluas jaringan pertemanan. Berkat situs media sosial ini anak menjadi lebih mudah berteman dengan orang lain di seluruh dunia. Meskipun sebagian besar di antaranya tidak pernah mereka temui secara langsung;

2. Anak dan remaja akan termotivasi untuk belajar mengembangkan diri melalui temanteman yang mereka jumpai secara online karena mereka berinteraksi dan menerima umpan balik satu sama lain;

3. Situs jejaring sosial membuat anak dan remaja menjadi lebih bersahabat, perhatian dan empati. Misalnya memberikan perhatian saat ada teman 
mereka berulang tahun, mengomentari foto, video dan status teman mereka, menjaga hubungan persahabatan meski tidak dapat bertemu secara fisik;

4. Menjalin silaturahmi terhadap teman-teman lama yang terputus komunikasi sebagai akibat dari perbedaan jarak dan waktu, sehingga silaturahmi yang terputus bisa terjalin kembali dengan baik;

5. Menambah ilmu pengetahuan dan teknologi, karena dengan penggunakan teknologi dengan jejaring sosial, secara langsung kita dapat menguasai penggunaan teknologi tersebut dan dapat menambah wawasan ilmu pengetahuan dengan membaca dan membuka link-link yang berkaitan dengan ilmu pengetahuan.

6. Media Sosial bisa digunakan untuk usaha atau kegiatan-kegiatan yang menghasilkan pendapatan bagi pengguna, misalnya menawarkan produk atau jasa yang kita jual melalui sosial media.

Dampak negatif dalam menggunakan media sosial, yaiti sebagai berikut:

1. Anak dan remaja menjadi malas belajar berkomunikasi di dunia nyata, tingkat pemahaman bahasapun menjadi terganggu, jika anak terlalu banyak berkomunikasi di dunia maya;

2. Situs jejaring sosial akan membuat anak dan remaja lebih mementingkan diri sendiri, mereka menjadi tidak sadar akan lingkungan di sekitar mereka, karena kebanyakan menghabiskan waktu menggunakan internet, hal ini dapat mengakibatkan menjadi kurang berempati di dunia nyata;

3. Bagi anak dan remaja, tidak ada aturan ejaan dan tata bahasa di situs jejaring sosial. Hal ini membuat mereka semakin sulit untuk membedakan antara berkomunikasi di situs jejaring sosial dan di dunia nyata;

4. Situs jejaring sosial adalah lahan yang subur bagi predator untuk melakukan kejahatan, kita tidak akan pernah tahu apakah seseorang yang baru kita kenal di internet menggunakan jati diri yang sesungguhnya atau tidak;

Banyaknya situs-situs porno yang bisa dengan mudah diakses oleh pengguna, hal ini bisa mempengaruhi terhadap perilaku pengguna atau masyarakat. Pemerintah dalam hal ini Menteri Komunikasi dan Informasi harus berbuat tegas dan masif untuk memblokir semua situs-situs porno yang beredar di internet atau media sosial, serta perlunya peran serta dan pengawasan pada lingkungan rumah dan sekolah.

\section{Penutup}

\subsection{Kesimpulan}

Adapun kesimpulan dalam artikel ini adalah sebaiknya dalam menggunakan media sosial sesuai dengan aturan yang berlaku dan tunduk pada Undang-Undang Republik Indonesia Nomor 19 Tahun 2016 Tentang Perubahan Atas Undang-Undang Republik Indonesia Nomor 11 Tahun 2008 Tentang Informasi dan Transaksi Elektronik. Serta perlunya peran aktif dari masyarakat dan orang tua dalam mengawasi 
anak dalam menggunakan media sosial supaya tidak terjerat dengan sanksi pidana dan/atau ganti rugi.

\subsection{Saran}

Adapun saran yang dapat peneliti berikan pada artikel ini adalah sebagai berikut:

a) Masyarakat dan orang tua harus berperan aktif dalam mengawasi dalam menggunakan media sosial; dan b) Pemerintah harus memblokir semua akun media sosial yang sifatnya mengandung SARA dan yang dapat membuat kegaduhan kehidupan berbangsa dan bernegara serta menimbulkan kegaduhan.

\section{DAFTAR PUSTAKA}

\section{A. Buku}

Burhan Ashofa. Metode Penelitian Hukum. Jakarta: Rineka Cipta, 2007.

Elkind D. Egocentrism In Adolescence. Child Development. 1967.

Setiono. Pemahaman Terhadap Metodologi Penelitian Hukum. Surakarta: Program Studi IImu Hukum Pasca Sarjana Universitas Sebelas Maret (UNS), 2010.

\section{B. Jurnal}

Mochammad Ali Maulidin, Syahirul Alim dan Viani Puspita Sari. "Cerdas dan Bijak Dalam Memanfaatkan Media Sosial Di Tengah Era Literasi dan Informasi." Jurnal Aplikasi Ipteks Untuk Masyarakat. Maret 2017: Volume 6. Nomor 1.

Pamela Felita, dkk. "Pemakaian Media Sosial dan Self Concept Pada Remaja." Jurnal IImiah Psikologi MANASA. Mei 2016: Volume 5. Nomor 1.

\section{Internet}

Erwin, Z. "Indonesia juara akses internet melalui smartphone." lihat dalam: http://tekno.tempo.co/ IndonesiaJuaraAksesInternetMelaluiSmartp hone, diakses pada 25 Mei 2018

Hendra. "Fenomena Internet Pada Anak-Anak dan Remaja."

http://hendra.room318online.com/Fenomen alnternetPadaAnak-AnakdanRemaja, diakses pada tanggal 23 Agustus 2018.

Qomariah A.N. "Perilaku Penggunaan Internet Pada Kalangan Remaja di Perkotaan." http://palimpsest.fisip.unair.ac.id/, diakses pada tanggal 23 Mei 2018.

\section{Peraturan Perundang-Undangan}

Undang-Undang Republik Indonesia Nomor 19 Tahun 2016 Tentang Perubahan Atas Undang-Undang Republik Indonesia Nomor 11 Tahun 2008 Tentang Informasi dan Transaksi Elektronik. 